\title{
Analysis of the runoff response of an alpine catchment at different scales
}

\author{
B. Zillgens ${ }^{1}$, B. Merz ${ }^{1}$, R. Kirnbauer ${ }^{2}$, and N. Tilch $^{3}$ \\ ${ }^{1}$ GeoForschungsZentrum Potsdam, Potsdam, Germany \\ ${ }^{2}$ Institute of Hydraulics, Hydrology and Water Resources Management, Vienna University of Technology, Vienna, Austria \\ ${ }^{3}$ Geological Survey of Austria, Department of Engineering Geology, Vienna, Austria
}

Received: 14 July 2005 - Published in Hydrol. Earth Syst. Sci. Discuss.: 9 September 2005

Revised: 13 April 2007 - Accepted: 2 July 2007 - Published: 18 July 2007

\begin{abstract}
To understand how hydrological processes are related across different spatial scales, 201 rainfall runoff events were examined in three nested catchments of the upper river Saalach in the Austrian Alps. The Saalach basin is a nested catchment covering different spatial scales, from the micro-scale (Limberg, $0.07 \mathrm{~km}^{2}$ ), to the small-catchment scale (Rammern, $15.5 \mathrm{~km}^{2}$ ), and the meso-scale (Viehhofen, $150 \mathrm{~km}^{2}$ ). At these three scales two different event types could clearly be identified, depending on rainfall characteristics and initial baseflow level: (1) a unimodal event type with a quick rising and falling hydrograph, responding to short duration rainfall, and (2) a bimodal event type with a double peak hydrograph at the micro-scale and substantially increased flow values at the larger basins Rammern and Viehhofen, responding to long duration rainfall events. In all cases where a bimodal event was identified at the microscale, the hydrographs at the larger scales exhibited significantly attenuated recession behavior, quantified by recession constants. At all scales, the bimodal events are associated with considerably higher runoff volumes than the unimodal events. From the investigations at the headwater Limberg we came to the conclusion that the higher amount of runoff of bimodal events is due to the mobilization of subsurface flow processes. The analysis shows that the occurrence of the two event types is consistent over three orders of magnitude in area. This link between the scales means that the runoff behavior of the headwater may be used as an indicator of the runoff behavior of much larger areas.
\end{abstract}

Correspondence to: $\mathrm{B}$. Merz

(bmerz@gfz-potsdam.de)

\section{Introduction}

This paper investigates the runoff response to rainfall in three nested catchments of the upper river Saalach in the Austrian Alps. The study area covers different spatial scales, from the micro-scale (Limberg, $0.07 \mathrm{~km}^{2}$ ), to the small-catchment scale (Löhnersbach basin, gauge Rammern, $15.5 \mathrm{~km}^{2}$ ), and the meso-scale (Viehhofen, $150 \mathrm{~km}^{2}$ ). Understanding runoff generation processes is essential for obtaining realistic estimates of runoff for unobserved situations, such as extreme floods or changed environmental conditions (e.g. Naef et al., 2002; Singh and Strupczewski, 2002; Weingartner et al., 2003). However, natural hydrological systems are characterized by tremendous variability in space, time and process (McDonnell and Woods, 2004). Runoff generation results from the interaction of different processes which vary with climate and catchment properties. One particularly challenging aspect is the understanding of the spatio-temporal patterns of runoff generation (Kirnbauer et al., 2005). This includes the variability of runoff processes from event to event and the variability across spatial scales. The dominance of processes may change with scale (Grayson and Blöschl, 2000); an observation which complicates hydrological understanding and modelling.

In particular, runoff generation in alpine regions is not well understood, even though mountainous regions have a significant impact on the hydrological cycle (Klemeš, 1993; Rodda, 1994; Viviroli et al., 2003) and are characterized by a high flood disposition (Wetzel, 2001). The investigation of runoff generation in alpine catchments is challenged by inaccessibility of these regions. Mountain streams can become torrential rivers during storms which mostly results in data gaps in hydrological time series, especially for the time periods

Published by Copernicus Publications on behalf of the European Geosciences Union. 
of highest interest. Another problem is the heterogeneity of the terrain and of the subsurface, where flow processes are highly influenced by complex geological formations.

Investigation of the runoff response in the headwater area Limberg have shown that different runoff mechanisms exist, dependent on moisture and precipitation characteristics (Kirnbauer et al., 2001), causing different hydrograph shapes. Short intensive storms during dry periods cause a quick runoff response and storm events during long duration rain periods cause a delayed peak in addition to the quick runoff response. The direct peak events are the quick response to rainfall (within minutes) and the delayed peak occurs as a delayed damped arch-shaped hydrograph. The delayed peaks can be observed approximately three days after the first peak, even if the rain has already stopped. The double peak event is of particular importance in the Löhnersbach catchment, because it was shown that simultaneous to double peak events in the headwater Limberg the hydrograph of the superordinate Löhnersbach watershed is characterized by substantially increased flow values of prolonged duration (Kirnbauer et al., 2001). During these times of increased runoff additional rain can cause flood discharges.

Double peak or bimodal events have been observed in other regions, too. Anderson and Burt (1978) measured delayed throughflow peaks in Sommerset, UK, in a small valley, with a one to two meter deep, freely drained soil layer on an impermeable subsurface. Onda et al. (2001) observed double hydrographs in western Japan for shale and serpentinite watersheds in steep mountainous regions. The second peak seems to be a result of delayed runoff from a deep subsurface flow system. Masiyandima et al. (2003) found bimodal events in an inland valley and surrounding contributing watershed area in central Côte d'Ivoire. The double peak events have in common that the delayed peak contributes considerably more runoff than the first peak. Onda et al. (2001) found the second peak discharge volume to be five to ten times greater than the volume of the first peak. In a watershed in central Côte d'Ivoire the first peak of the double peak event occurred during the rainfall event and was caused by rain falling on the saturated valley bottom. The second peak was delayed by minutes and hours and consisted of rain flowing via the subsurface of the hydromorphic zone that surrounds the valley bottom (Masiyandima et al., 2003).

Tracer methods have become an important tool for decoding runoff generation processes in mountainous regions (e.g. Vitvar et al., 1999; Uhlenbrook et al., 2002; Tilch et al., 2003; Weiler et al., 2003) and can provide information about flow pathways, residence time and runoff formation. Tracer investigations in the headwater area Limberg showed that the fast peak consists of pre-event water (old water stored in the catchment) and event water (from the current rain event), originating from saturation areas and episodic interflow processes of the drift cover (Tilch et al., 2003; Kirnbauer et al., 2004). The second peak consists exclusively of pre-event water from fissured bedrock and deep quaternary drift covers.
Another method for understanding runoff generation processes is the analysis of the shape of hydrographs. Hydrograph characteristics are a function of spatial and temporal characteristics of precipitation and physical features of the catchment, including rainfall duration and intensity, drainage area morphology, topography, geology, vegetation, soil water storage and depression storage. Runoff contributions from different compartments, storages and flow pathways vary with event characteristics and can result in different hydrograph shapes (Jenkins et al., 1994; Gutknecht, 1996).

McNamara et al. (1998) used hydrograph analysis to assess the importance of saturation areas for fast runoff generation in an artic river basin. Rose and Peters (2001) could demonstrate the effects of urbanization on stream flow. A specific characteristic of a hydrograph is the recession behaviour of the falling limb which reflects various physical watershed factors. Recession curve analysis is widely used to describe the storage-outflow relationship for river catchments (e.g. Hall, 1968; Nathan and McMahon, 1990; Tallaksen, 1995; Chapman, 1999; Wittenberg and Sivapalan, 1999; Mendoza et al., 2003; Sujono et al., 2004). In most cases, the aim of such analyses is to describe the behaviour of groundwater reservoirs, and to quantify discharge, evapotranspiration loss, storage and recharge. An overview of recession curve analysis is given by Tallaksen (1995) and Dewandel et al. (2003); and different techniques are compared by Chapman (1999) and Sujono et al. (2004).

The objective of this paper is to study the runoff response to rainfall in the three nested alpine catchments of the upper river Saalach and to understand how this response behaves across spatial scales. Characteristics of the two event types, referred to as unimodal and bimodal event type, are analyzed by hydrograph and recession analysis for the headwater catchment Limberg $\left(0.07 \mathrm{~km}^{2}\right)$. Further, the analysis is extended to the two larger basins, the Löhnersbach basin $\left(15.5 \mathrm{~km}^{2}\right)$ and the upper Saalach basin $\left(150 \mathrm{~km}^{2}\right)$. It is investigated if the typical runoff behavior at the headwater scale, i.e. the occurrence of unimodal and bimodal events, can also be found at the larger scales, and if this behavior is consistently linked to event characteristics.

\section{Investigation site}

\subsection{Catchment characteristics}

The Saalach catchment is located in the eastern Alps near Salzburg (Austria) and is part of the Northern Greywack Zone. Viehhofen is a nested catchment of the upper Saalach stream covering different scales, from the micro-scale (Limberg, $0.07 \mathrm{~km}^{2}$ ), to the small-catchment scale (Löhnersbach, up to Rammern gauge, $15.5 \mathrm{~km}^{2}$ ), and the meso-scale (Saalach, up to Viehhofen gauge, $150 \mathrm{~km}^{2}$ ). The Saalach region is dominated by continental climatic conditions. The elevation ranges from $2360 \mathrm{~m}$ down to $820 \mathrm{~m}$ a.s.l. at the 


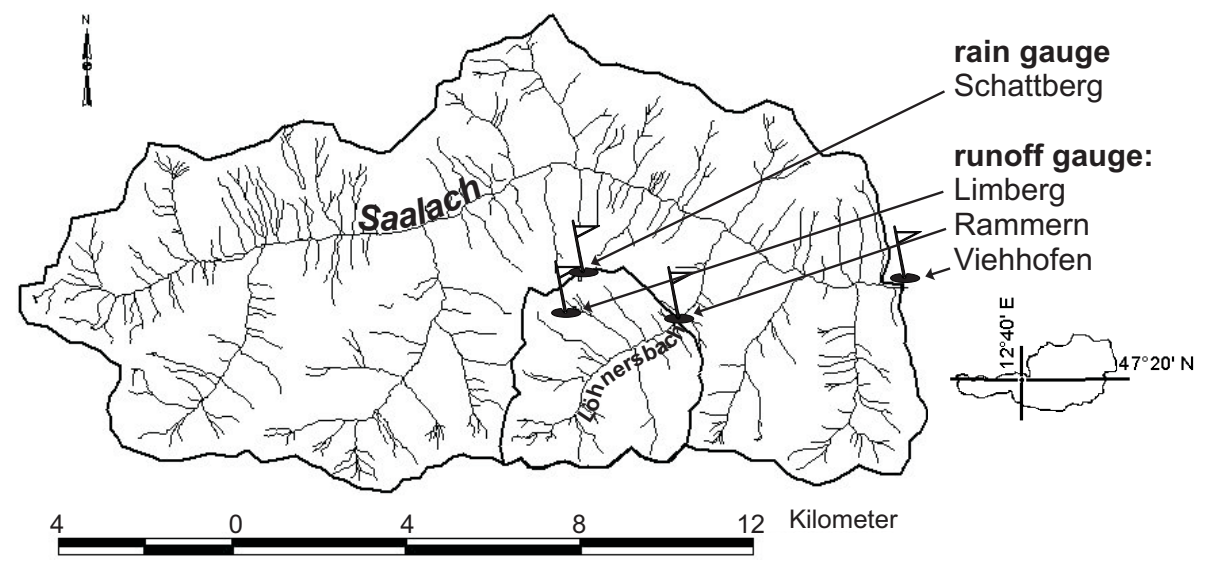

Fig. 1. Map of the nested study area of the upper Saalach basin: upper Saalach $\left(150 \mathrm{~km}^{2}\right.$, gauge Viehhofen), Löhnersbach $\left(15.5 \mathrm{~km}{ }^{2}\right.$, gauge Rammern), and Limberg $\left(0.07 \mathrm{~km}^{2}\right.$, gauge Limberg).

stream gauge Viehhofen. The annual precipitation is about $1400 \mathrm{~mm}$. Spacious luff and lee effects are rather insignificant and are superimposed by regional thunder storms. The monthly runoff of the upper Saalach and the Löhnersbach is characterized by a maximum in May due to snow melt. Storm runoff maxima tend to occur during summer due to heavy thunder storms. During snow accumulation in winter the streams have constant low flow rates with a minimum in January/February. In summer, baseflow decreases with decreasing snow melt (HDÖ, 2002).

The catchment of the brook Löhnersbach has a size of $15.5 \mathrm{~km}^{2}$ up to the runoff gauge Rammern with elevations ranging from 1100 to $2250 \mathrm{~m}$ a.s.l. The Löhnersbach brook flows at an elevation of $920 \mathrm{~m}$ into the Saalach and has the character of a mountain torrent. In previous years, a lot of research has been carried out in the Löhnersbach area, because extreme storm events repeatedly caused landslides and debris flows, which are a high risk for settlements close to the stream. Slopes in the Löhnersbach catchments are steep, with a mean value of nearly $42 \%$ (standard deviation 13\%) based on a $10 \mathrm{~m}$ grid. Thus, concentration times are rather small: Estimated by the method proposed by Morgali and Linsley (1965), they amounted to $1.5 \mathrm{~h}$ with a coefficient of variation of 0.5 . Soil types and soil physical properties were investigated and mapped by Markart and Kohl (1993a, b, unpublished reports), who found saturated conductivities between 24 and $520 \mathrm{~mm} / \mathrm{h}$ with a mean value of $177 \mathrm{~mm} / \mathrm{h}$ and field capacities of about $50 \mathrm{~mm}$. A vegetation map was established by Schiffer and Burgstaller (1990, unpublished report). Table 1 which gives the relative fraction of land cover types in the Löhnersbach catchment is based on this map, after digitizing it to a $10 \mathrm{~m}$ grid. Information about geology, hydrogeology and stream network including saturation areas is given by Pirkl (1989, unpublished report). Rainfall runoff characteristics are monitored since 1991 by the Institute of Hydraulics, Hydrology and Water Resources Management
Table 1. Vegetation in the Löhnersbach catchment.

\begin{tabular}{ll}
\hline Vegetation type & $\%$ of total area \\
\hline roads, settlements & 0.27 \\
alpine and subalpine pioneering vegetation & 3.20 \\
meadows containing nardus stricta & 20.07 \\
meadows & 0.81 \\
subalpine shrub & 34.52 \\
dwarf pine & 0.29 \\
green alder, brushwood & 3.07 \\
spruce forest & 31.68 \\
deciduous forest & 2.11 \\
fen, swamp & 2.61 \\
deforested & 1.36 \\
Total & 100.00 \\
\hline
\end{tabular}

at the Vienna University of Technology. The instrumentation consists mainly of stream and rain gauges. Figure 1 shows the location of the instrumentation relevant for this paper, namely the runoff gauges at Limberg, Rammern and Viehhofen and the rain gauge at Schattberg. The Viehhofen runoff gauge is operated by the Austrian Hydrographic Service, Salzburg Section.

In the Löhnersbach catchment the headwater Limberg became the main field of activity at the micro-scale (Tilch et al., 2003; Kirnbauer et al., 2004). The stream gauge, at an altitude of $1780 \mathrm{~m}$ a.s.l., is located at the natural outlet of a saturation area. The highest point of the catchment is $2000 \mathrm{~m}$ a.s.l. The greatest distance between runoff gauge and catchment boundary is about $500 \mathrm{~m}$. The nearest rain gauge is located outside of the catchment. The minimum distance from the headwater to the rain gauge is approximately $840 \mathrm{~m}$ with an elevation difference of $180 \mathrm{~m}$. 

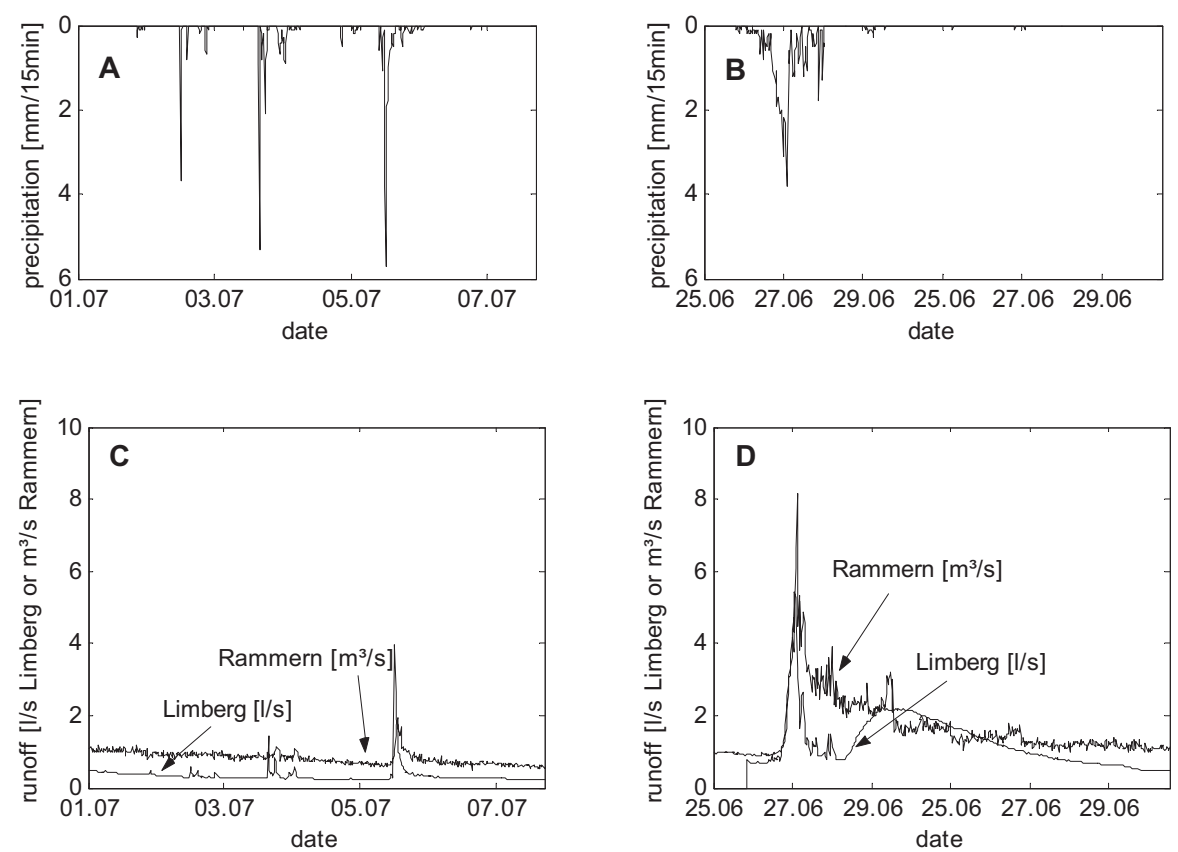

Fig. 2. Typical hydrographs of the micro-scale catchment at stream gauge Limberg and meso-scale catchment at stream gauge Rammern (year 1995): direct and synchronic runoff peaks (C) during short and intensive rainstorms (A), and bimodal runoff events (D) during and after moderate and much longer rainfall events (B) (Kirnbauer et al., 2001, modified).

\subsection{Runoff response in the Löhnersbach catchment}

In the Löhnersbach catchment different runoff characteristics were identified (Kirnbauer et al., 1996, 2001, 2005). The Löhnersbach divides the catchment into a north-western and south-eastern part. The runoff response of both parts differs. During low flow conditions, the north-western part contributes to runoff below average and the south-eastern part above average. For high flow conditions and large rain events this trend is reversed. Furthermore, different event types could be identified at the micro-scale (gauge Limberg) and the small-catchment scale (gauge Rammern). Figure 2 shows typical hydrographs at gauge Limberg [1/s] and at gauge Rammern $\left[\mathrm{m}^{3} / \mathrm{s}\right]$. Direct and synchronic runoff peaks (C) occur during short and intensive rainstorms (A) at both scales. For long duration rainfall events with low rainfall intensity (B), bimodal runoff events can be observed at Limberg (D). Simultaneously to the bimodal runoff events at Limberg an increased runoff volume with a slowly abating recession curve can be measured at Rammern gauge (D). Bimodal runoff response could be identified in a different headwater in the Löhnersbach catchment, too, and is not only a specific phenomenon of the Limberg catchment (Tilch et al., 2003). For the small-catchment scale (gauge Rammern), it seems quite evident that the shape of the recession curve is a result of different "delayed peaks" from other locations, which occur in sum as a substantially increased hydrograph with long recession time.

\subsection{Headwater Limberg}

The headwater Limberg is located on the lateral part of a glacier. Accordingly, the geological conditions are very complex, where subsurface flow pathways are difficult to identify. The micro-scale catchment Limberg can roughly be divided into three major geographic-geological units (see Fig. 3). The highest unit, and furthest from the stream gauge, is a boulder field with very steep slope and a high macroporosity, underlain by low metamorphic and fractured greywake and siltstone. Downhill in more flat positions is a cirque area with a frontal rim, caused by a combined rock and debris block slide. This area is characterized by thick duff layer under alpine rose vegetation, some small pools and saturation areas. At the foot of the frontal rim is a saturation area fed by springs from the base of the slide mass and from inside the saturation area. Some of the springs are permanent, some are only active during wet conditions. The sources providing permanent base flow are most likely supplied by additional areas from deep storage water systems.

By the use of artificial tracers and the analysis of natural tracers, flow components and generation areas in the headwater could be identified. This work is discussed in detail by Tilch et al. (2003). The tracer investigations support the conclusions of Kirnbauer et al. $(1996,2001)$ that the unimodal peak is generated at the saturation areas and contains rain water. But pre-event water from the saturation areas could be detected in the peak flow, too. It is assumed that water, which is stored in depressions due to pasturing, gets flushed 


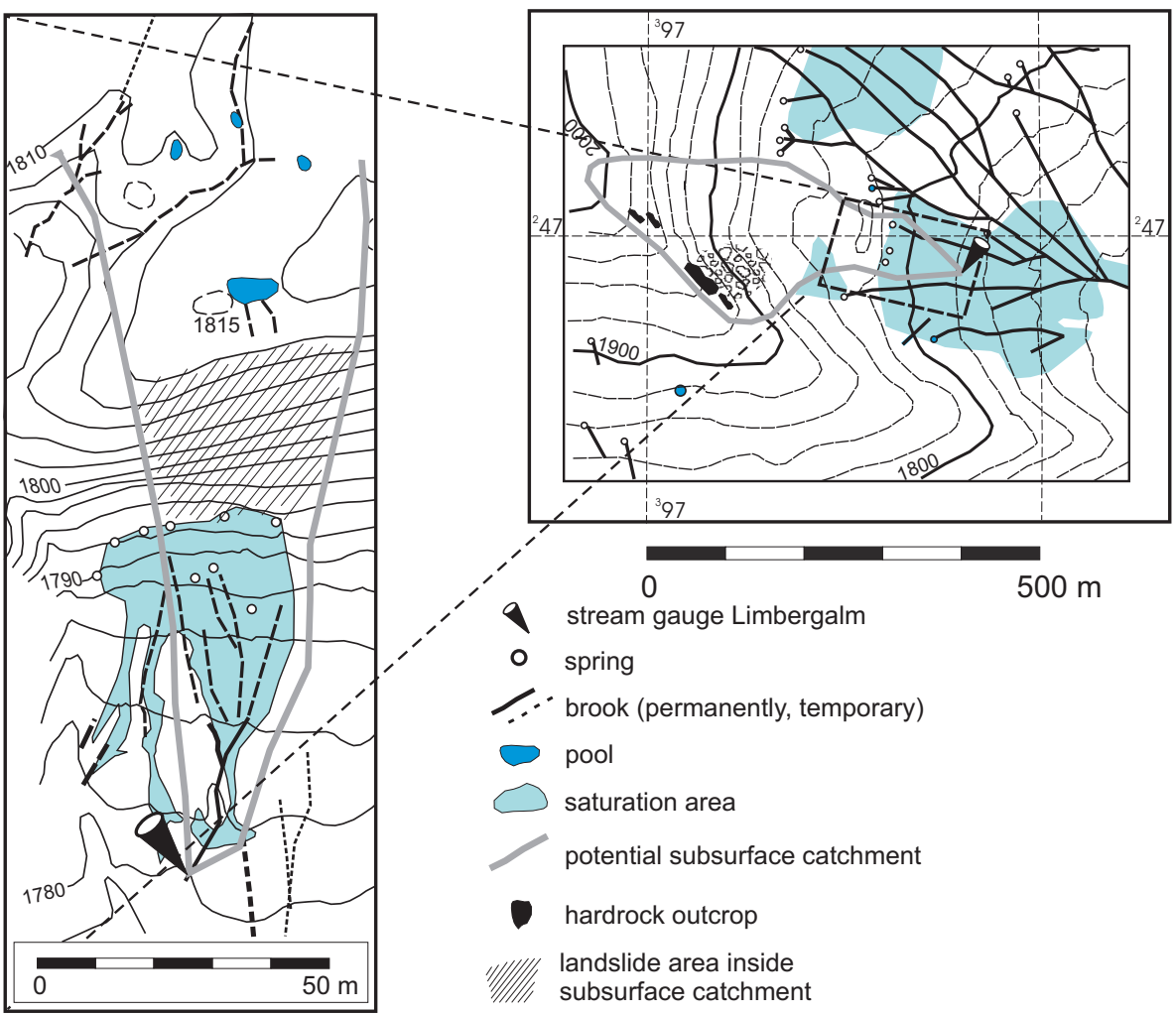

Fig. 3. Headwater catchment Limberg with stream network, saturation areas, ponds and springs (Tilch et al., 2003, modified).

out by rain during a storm event. In the frontal rim within and under the duff layer fast episodic runoff is generated, too. After saturation the duff layer generates interflow. The delayed peak consists solely of pre-event water. At least two subsurface flow systems could be identified. Newer investigations (Kirnbauer et al., 2004) prove that the water moves at least along two pathways with different attenuation and storage properties (boulder field at the very steep hillslope, and the metamorphic and fractured greywake and siltstone). Unlike the delayed peak, the permanent subsurface flow comes from deeper storage systems.

\section{Data and methods}

\subsection{Rainfall runoff events}

Rainfall and runoff time series of 67 storms of the years 1997-2002 were analyzed at all scales (micro-scale, smallcatchment scale, meso-scale). The time series are given in intervals of $15 \mathrm{~min}$. The events were taken from the period when there was no (or negligible) snow cover and when the temperature was above $0^{\circ} \mathrm{C}$ (usually end of June). The beginning of an event depends on the onset of rain measured at the Schattberg gauge. An event is defined to start one time step before the precipitation begins (the hydrograph rises in the same time step as rainfall occurs). The initial base flow is defined as the discharge of the first time step. It characterizes the base flow conditions before the hydrograph response to a rain impulse.

These 67 events, identified at the gauge Limberg, were not only analyzed at the gauge Limberg but also at the gauges Rammern and Viehhofen. It is assumed that these events affect the whole catchment up to Viehhofen with $150 \mathrm{~km}^{2}$. For the same time segments, taken at Limberg, the hydrographs measured at the Rammern and Viehhofen gauges were analyzed. The beginning of an event is the same for all scales. The duration of an event is taken individually according to the decay characteristics of the hydrographs at the different scales.

\subsection{Hydrograph analysis and event types}

At the Limberg scale unimodal and bimodal event types can directly be identified from the shape of the hydrograph. For all events analyzed, the same event types at the micro-scale can also be found at the Rammern and Viehhofen scales. Considered characteristics are rainfall volume and intensity, initial runoff, storm runoff volume and recession constants. They are explained in detail in Sects. 3.3 and 3.4. To quantify the runoff response the hydrographs were separated into direct storm runoff and baseflow, for which several techniques exist. In this application a straight line separation seems 


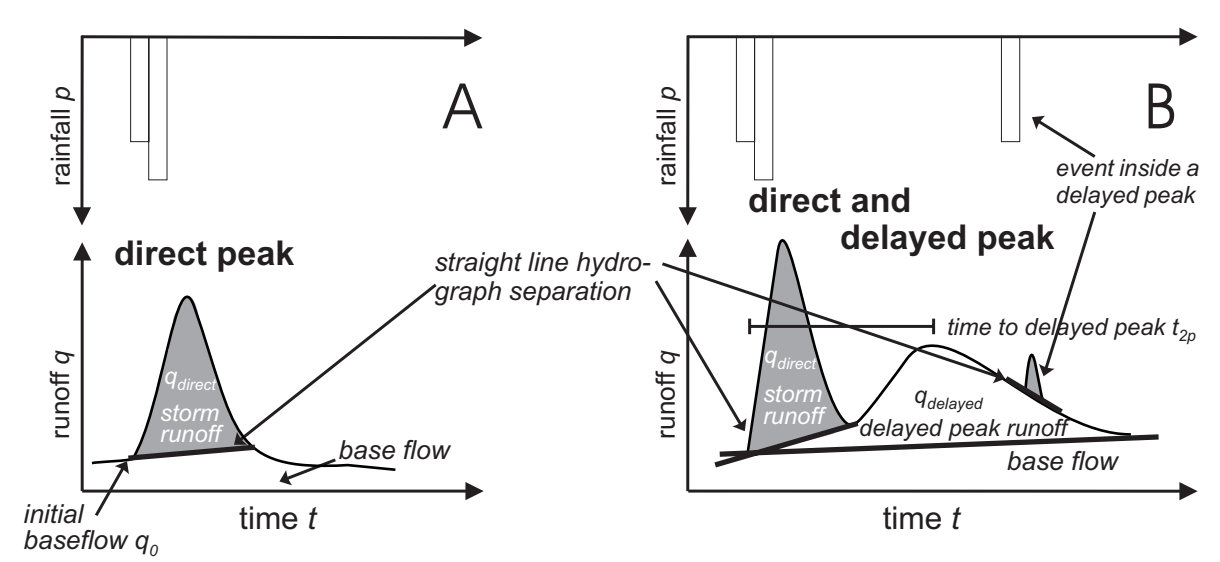

Fig. 4. Schematic representation of the hydrographs of an unimodal peak event (A) and a bimodal peak event (B).

Table 2. Number of runoff events for the two event types.

\begin{tabular}{cccc}
\hline year & $\begin{array}{c}\text { unimodal } \\
\text { event }\end{array}$ & $\begin{array}{c}\text { bimodal } \\
\text { event }\end{array}$ & time period \\
\hline 1997 & 5 & 3 & 22 June-13 Sep \\
1998 & 13 & 1 & 27 June-28 Sep \\
1999 & 13 & 4 & 21 June-28 Sep \\
2000 & 8 & 2 & 10 July-3 Oct \\
2001 & 7 & 2 & 16 June-8 Aug \\
2002 & 9 & - & 27 June-10 Sep \\
total & 55 & 12 & \\
\hline
\end{tabular}

adequate because we wish to compare water volume mobilized by a rainfall event independent of the source area. The line was projected from the initial rise of the hydrograph to the point on the falling limb where a break in slope occurred (point of inflection on the falling limb).

\subsection{Event types}

The runoff events are subdivided into unimodal and bimodal event types (Table 2). In Fig. 4 the two types measured at the Limberg gauge are drawn schematically (see also Fig. 1). The unimodal event type is characterized by a peak that directly responds to the rainfall impulse. A rainfall event can have more than one impulse so that the hydrograph responds with more than one direct peak. A bimodal event consists of a direct peak response and a delayed peak as a response to the same rain impulse that initiated the direct peak.

In this paper storm runoff is defined as the direct response to a rainfall impulse minus base flow calculated by the straight-line separation. The delayed peak runoff volume is the volume generated in the delayed "damped" peak minus base flow volume. For bimodal events, the onset of a delayed peak cannot be seen in the hydrograph, because the delayed peak intermixes with the direct peak reaction. We assume that the delayed peak response starts at the same time as the direct peak response. Storm runoff events caused by rainfall impulses within a delayed peak were separated by straightline separation and were not included in the delayed peak runoff (see Fig. 4b). The time to delayed peak is defined as the time from the beginning of the direct peak event to the maximum discharge of the delayed peak.

\subsection{Recession analysis}

Recession curve analysis was used to show that unimodal and bimodal event types exist not only at the micro-scale but also at the small-catchment scale and at the meso-scale. A delayed peak can only be identified as a wave-shaped hydrograph at the headwater Limberg. We hypothesize that if a delayed peak occurs at the headwater, the hydrographs at the larger scales (Rammern and Viehhofen) are characterized by significantly retarded recession. Therefore, recession coefficients were calculated for all events at Rammern and Viehhofen. Two approaches were used. First, a simple and widely used method is chosen based on the assumption of a linear reservoir outflow. The runoff values of the recession limb of an event were plotted against time as a semilogarithmic function (Pilgrim and Cordery, 1993). If the behavior of this semi-logarithmic function is linear, then the inverse of its slope (the inverse of the semi-logarithmic gradient) is equal to $K_{r}^{t}$ with values between 0 and 1 .

The recession function is described by:

$q_{t}=q_{0} \times K_{r}^{t}$

$$
\begin{aligned}
& t=\text { time }[\text { day }(86400 \mathrm{~s})] \\
& q_{t}=\text { discharge }\left[\mathrm{m}^{3} / \mathrm{s}\right] \\
& q_{0}=\text { initial discharge }\left[\mathrm{m}^{3} / \mathrm{s}\right] \\
& K_{r}^{t}=\text { recession constant }
\end{aligned}
$$



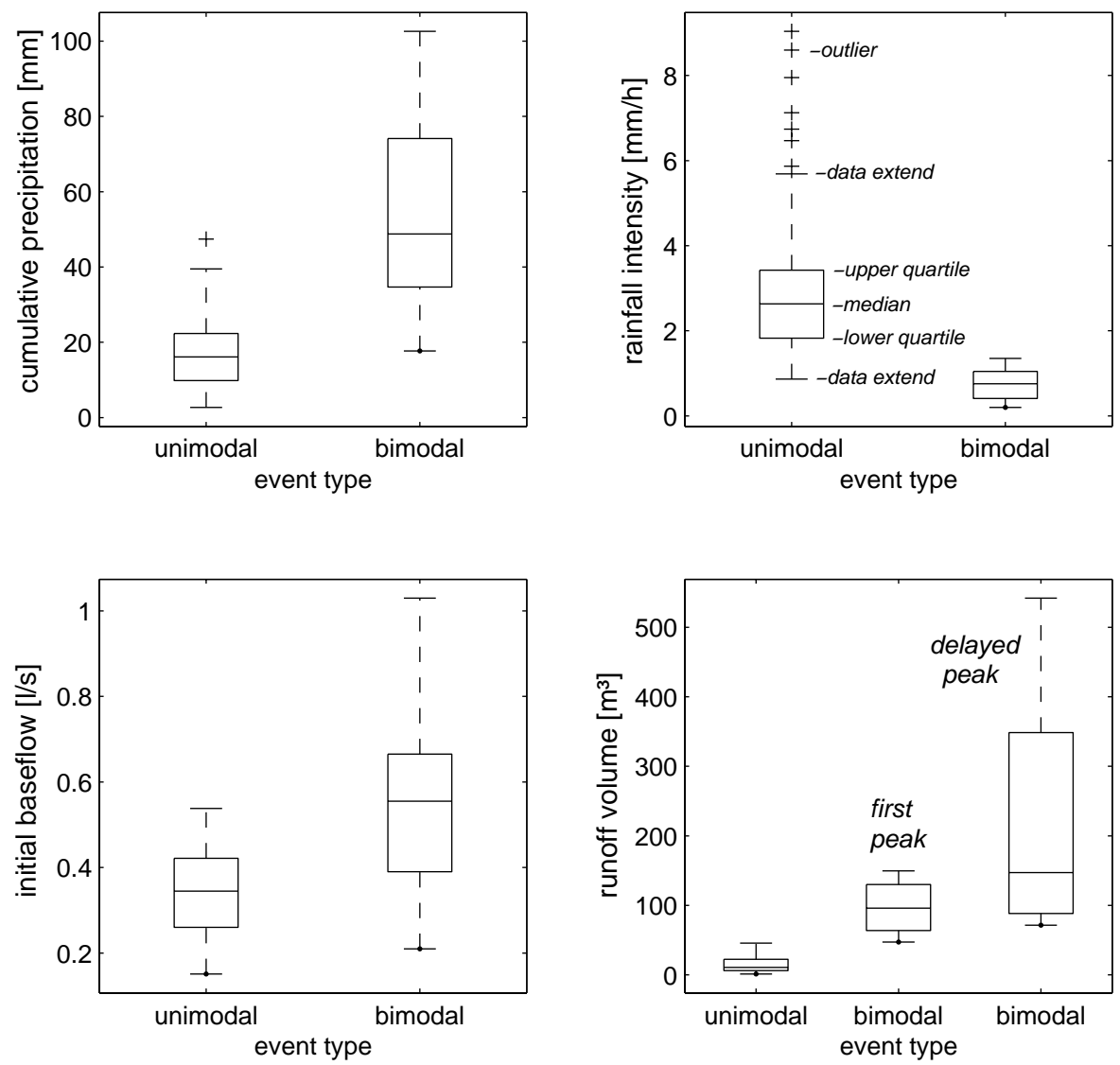

Fig. 5. Comparison of cumulative precipitation, rainfall intensity, initial baseflow and runoff volume for unimodal and bimodal events. The whiskers of the box plots extend to the minimum and maximum data value, however, not more than $1.5 \times$ interquartile range.

$K_{r}^{t}$ is a dimensionless quantity whose value depends on the time unit chosen. The $\log (q)$ values were fitted to a straight line with the coefficients $a\left[\mathrm{~m}^{3} \times(\mathrm{s} \times 86400 \mathrm{~s})^{-1}\right]$ and $b\left[\mathrm{~m}^{3} / \mathrm{s}\right]$ :

$\log (q)=a \times t+b$

with $K_{r}^{t}$ resulting from:

$K_{r}^{t}=\exp (a)$

Because various authors have shown that the storagedischarge relationship is non-linear (Kubota and Sivapalan, 1995; Wittenberg, 1999, 2003; Wittenberg and Sivapalan, 1999) a nonlinear outflow method according to Wittenberg (1999) was applied to the recession curves (Eq. 4). In this case, the recession flow hydrograph was estimated by fitting the discharge data $q_{t}$ to the non-linear storage outflow model:

$q_{t}=q_{0}\left(1+\frac{(1-b) \times q_{0}^{1-b}}{a \times b} \times t\right)^{\frac{1}{b-1}}$

For $q_{t}$ and $q_{0}$ in $\left[\mathrm{m}^{3} / \mathrm{s}\right]$ the factor $a$ has the dimension $\mathrm{m}^{3-3 b} \mathrm{~s}^{b}$ and $b$ is dimensionless. It has been found for numerous rivers in different hydrological regimes that $b$ is less
Table 3. Characteristics of the unimodal events measured at the headwater Limberg.

\begin{tabular}{lcccccc}
\hline 55 events & $\begin{array}{c}t_{e} \\
{[\mathrm{~d}]}\end{array}$ & $\begin{array}{c}\mathrm{p} \\
{[\mathrm{mm}]}\end{array}$ & $\begin{array}{c}p_{i} \\
{[\mathrm{~mm} / \mathrm{h}]}\end{array}$ & $\begin{array}{c}p_{i-\max } \\
{[\mathrm{mm} / \mathrm{h}]}\end{array}$ & $\begin{array}{c}q_{0} \\
{[1 / \mathrm{s}]}\end{array}$ & $\begin{array}{c}q s \\
{\left[\mathrm{~m}^{3}\right]}\end{array}$ \\
\hline median & 0.41 & 16.1 & 2.63 & 10 & 0.35 & 10.69 \\
minimum value & 0.11 & 2.7 & 0.86 & 2 & 0.15 & 1.16 \\
maximum value & 2.32 & 74.4 & 9.04 & 44 & 0.54 & 45.71 \\
\hline
\end{tabular}

$t_{e}$, event duration; $p$, total rainfall; $p_{i}$, precipitation intensity; $p_{i-\max }$, maximum precipitation intensity; $q_{0}$, initial baseflow; $q s$, storm runoff

than 1, with typical values around 0.5 (Wittenberg, 1994, 1999; Wittenberg and Sivapalan, 1999; Aksoy and Wittenberg, 2001; Mishra et al., 2003). For a fixed $b, a$ characterizes the recession behavior of the falling limb. With increasing $a$, the shape of the recession limb becomes increasingly damped. To get a clear interpretable parameter $a, b$ was fixed at 0.5 and $a$ und $q_{0}$ were fitted with a non-linear least square fitting method. 
Table 4. Characteristics of the bimodal events measured at the headwater Limberg.

\begin{tabular}{lllllllll}
\hline event & start & $\begin{array}{l}t_{e} \\
{[\mathrm{~d}]}\end{array}$ & $\begin{array}{l}q_{0} \\
{[\mathrm{l} / \mathrm{s}]}\end{array}$ & $\begin{array}{l}t_{2 p} \\
{[\mathrm{~d}]}\end{array}$ & $\begin{array}{l}p_{\text {direct }} \\
{[\mathrm{mm}]}\end{array}$ & $\begin{array}{l}p_{i} \\
{[\mathrm{~mm} / \mathrm{h}]}\end{array}$ & $\begin{array}{l}p_{i-\max } \\
{[\mathrm{mm} / \mathrm{h}]}\end{array}$ & $\begin{array}{l}q s_{\text {direct }} \\
{\left[\mathrm{m}^{3}\right]}\end{array}$ \\
\hline$* 1$ & 22 June 1997 & 15.02 & 0.73 & 3.35 & 28.7 & 0.60 & 1.2 & 61.32 \\
2 & 5 July 1997 & 17.69 & 0.55 & 4.90 & 102.6 & 1.35 & 5.5 & 149.75 \\
{$\left[\mathrm{~m}^{3}\right]$}
\end{tabular}

$t_{e}$, event duration; $q_{0}$, initial baseflow; $t_{2 p}$, time to second peak; $p_{\text {direct }}$, rainfall during direct peak duration; $p_{i}$, rainfall intensity; $p_{i-\text { max }}$, maximum precipitation intensity; $q s_{\text {direct }}$, storm runoff from direct peak, $q s_{\text {delayed }}$, storm runoff from delayed peak precipitation is underestimated due to measurement errors and temperatures $<0^{\circ} \mathrm{C}$
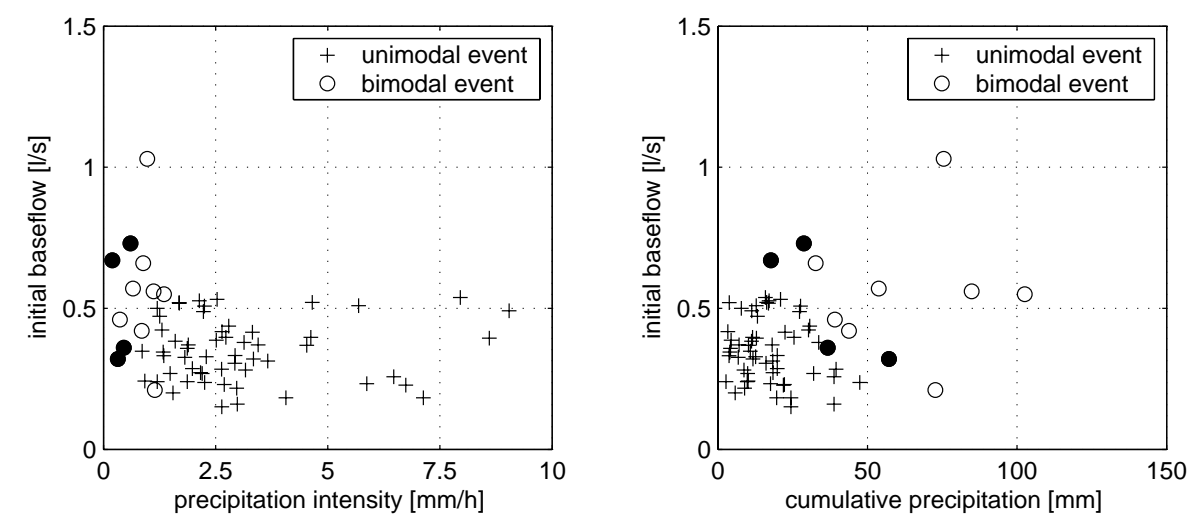

Fig. 6. Hydrological characteristics of the two event types (unimodal and bimodal) of the micro-scale catchment, stream gauge Limberg. Filled circles indicate bimodal events with underestimated precipitation due to measurement errors.

\section{Results}

\subsection{Runoff response of headwater Limberg}

In Fig. 5 cumulative precipitation, rainfall intensity, initial baseflow and runoff volume of the two event types are compared (see also Tables 3 and 4). The bimodal events show higher cumulative precipitation, lower rainfall intensities and higher initial base flow levels than the unimodal events. The runoff volume of bimodal events exceeds the runoff volume of unimodal peaks. The first peak of a bimodal event yields, compared to the unimodal peak event, more than the double runoff volume, and could be a result of the higher rainfall volume. Further, the delayed peak contributes at least half of the runoff volume of the first peak (Table 4, event 8) and can exceed the runoff of the first peak up to eight times (Table 4, event 10). The bimodal events follow the same trend determined by Kirnbauer et al. (2001). For six bimodal and six unimodal events they show that the bimodal events occur under relatively high precipitation depths (greater than $40 \mathrm{~mm}$ ), relatively low rainfall intensities (between 4 and $10 \mathrm{~mm} / \mathrm{h}$ ), and wet conditions, i.e. high initial base flow. The threshold values for bimodal runoff response given by Kirnbauer et al. (2001) differ slightly from the values found here and have overlapping ranges in the case of cumulative precipitation, rainfall intensity and initial baseflow. Overall, the event characteristics at Limberg shown in Fig. 5 are statistically significantly different for both event types which was proven by the Wilcoxon test of equality of medians at a significance level of $\alpha=0.01(99 \%)$.

The occurrence of the two event types, unimodal and bimodal, depends on the rainfall characteristics and on the soil 


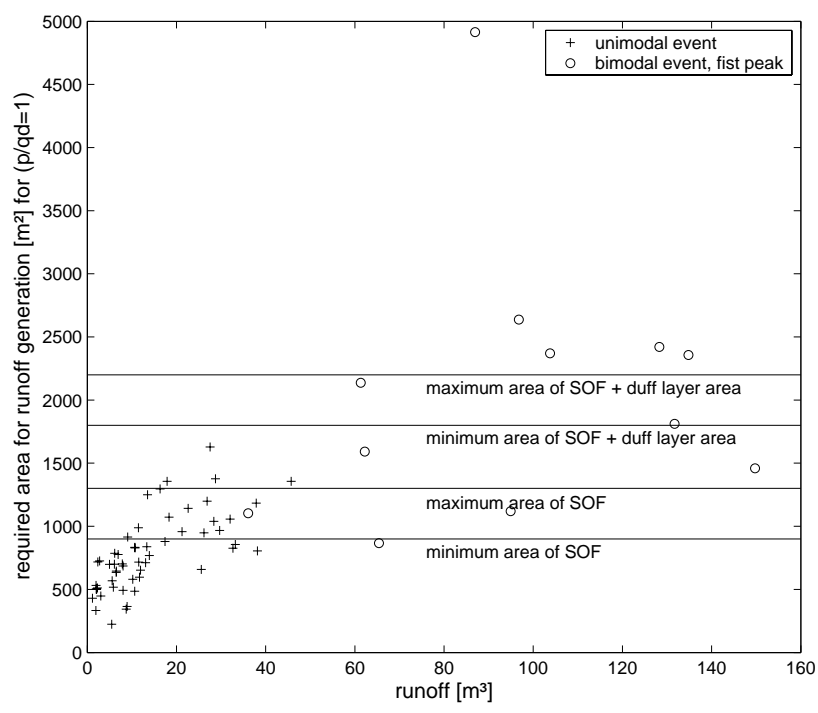

Fig. 7. Required area to generate the observed runoff volume of the first peak of bimodal events and of the unimodal events, under the assumption that the event runoff coefficient equals 1 (SOF: saturation area).

moisture state of the catchment. In Fig. 6, for all 67 events, initial baseflow as indicator of the soil moisture state is plotted versus precipitation intensity and cumulative precipitation, respectively. The two event types occur under very different event characteristics and form two separate groups (Fig. 6). A low rainfall height can produce a delayed peak (Fig. 6, right), but only if the initial baseflow is high (e.g. rainfall height $=17.7 \mathrm{~mm}$, initial baseflow $=0.67 \mathrm{l} / \mathrm{s}$, Table 4). If the initial baseflow is low a high rainfall amount is necessary to initiate a delayed peak (e.g. rainfall height $=$ $72.7 \mathrm{~mm}$, initial baseflow $=0.21 \mathrm{l} / \mathrm{s}$, Table 4). In contrast, bimodal events are always characterized by relative low precipitation intensities independent of initial baseflow (Fig. 6, left). It seems that the delayed peak results from an overflow of a storage system where, depending on the current water content, more or less rain input is needed to initiate a delayed peak.

The relationship between the runoff volume of the delayed peak and the two variables that represent the amount of water in the system, i.e. initial baseflow and cumulative precipitation, has not been explored in detail. To identify such a relationship or its determining factors a much larger sample (more than 12 bimodal events) would be necessary. Furthermore, the volume estimates of rainfall and runoff are crude estimates. For 4 out of 12 bimodal events the rainfall volume is underestimated due to measurement problems, and the derivation of the runoff volume of the delayed peak is subjective due to the subjective separation between the first und the second peak.

In Fig. 7 the required size of the generation area of the unimodal events and of the direct peak of the bimodal events
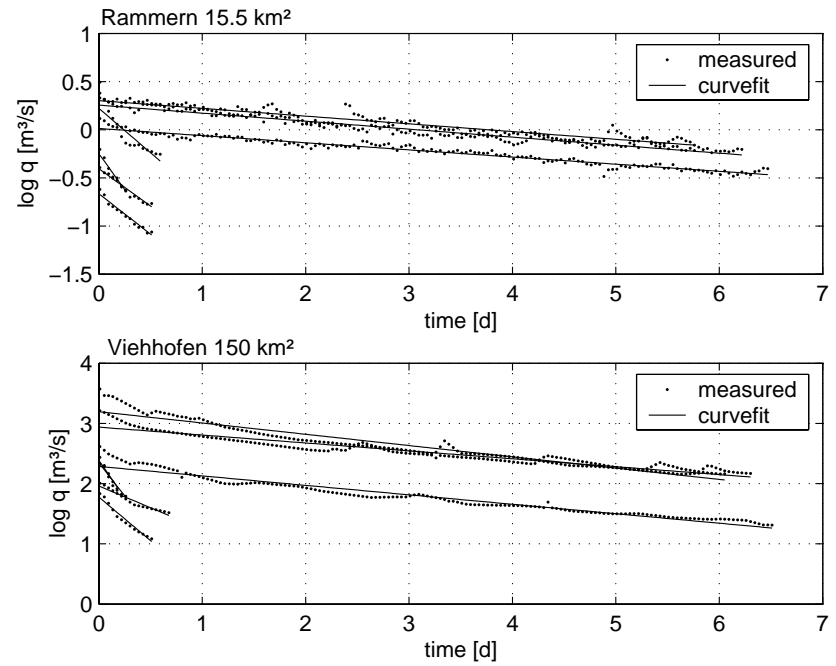

Fig. 8. Recession curves for the rainfall runoff events measured 1997 (every forth measured point is plotted) for Rammern and Viehhofen: linear model.
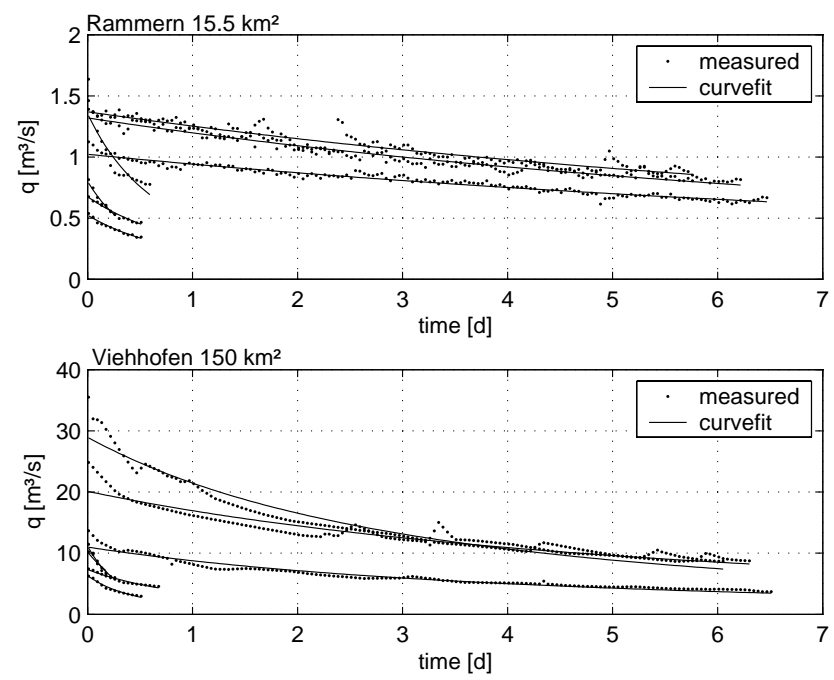

Fig. 9. Recession curves for the rainfall runoff evens measured 1997 (every forth measured point is plotted) for Rammern and Viehhofen: nonlinear model.

is plotted under the assumption that the entire rain is transformed into runoff (event runoff coefficient=1). A minimum and maximum extension of the saturation area of 900 and $1300 \mathrm{~m}^{2}$, respectively, was mapped during field investigations and is drawn as a line in Fig. 7. This demonstrates that the saturation area explains only the generation of runoff for small unimodal events. Other hydrological response units must generate direct runoff, too. The size of the duff layer area generating fast runoff after saturation is approximately $900 \mathrm{~m}^{2}$. However, neither saturation area nor duff layer area as an additional source of direct runoff explain all runoff events, particularly the direct peaks of the bimodal events. 

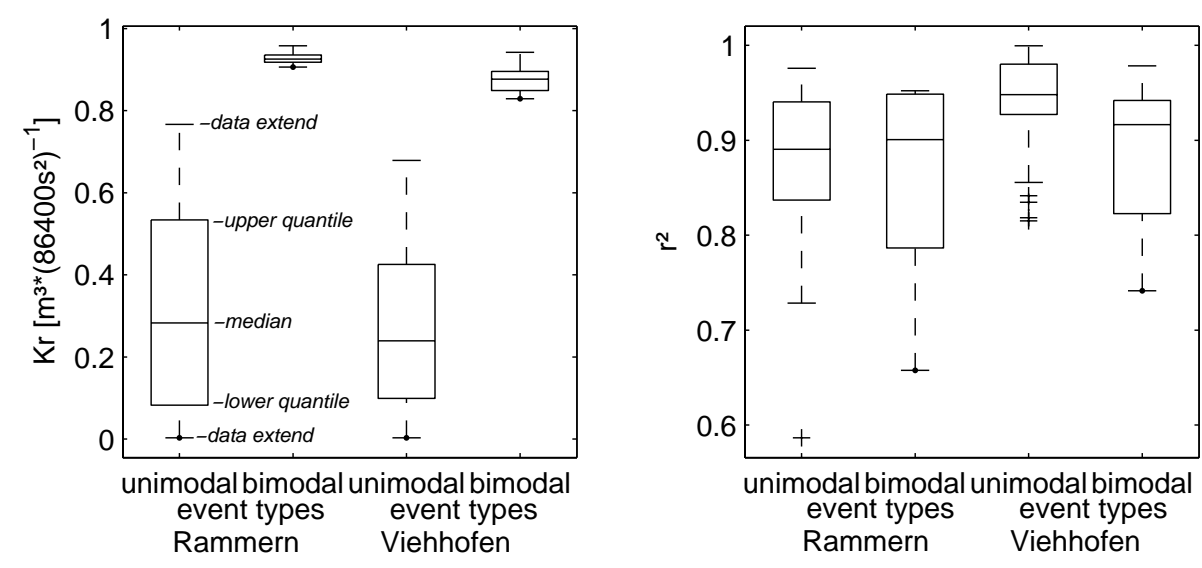

Fig. 10. Box plots of recession coefficients $K_{r}^{t}$ (left) with goodness of curve fit $r^{2}$ (right) for the unimodal and bimodal event types at the small-catchment scale (gauge Rammern) and at the meso-scale (gauge Viehhofen).
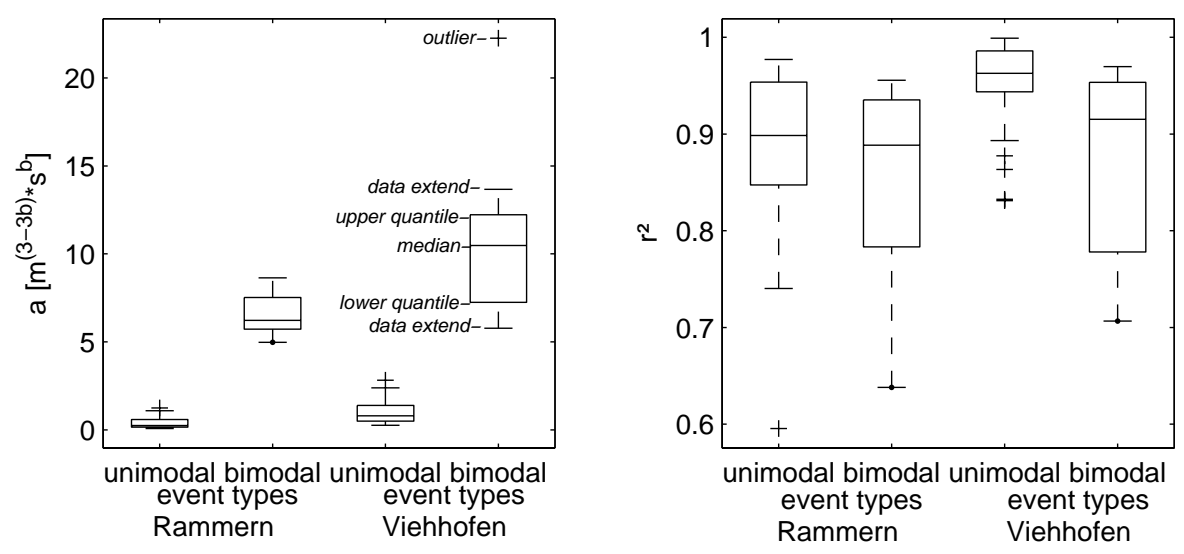

Fig. 11. Boxplots of coefficient $a$ (left) calculated with the nonlinear model with goodness of curve fit $r^{2}$ (right) for the two event types at the small-catchment scale (gauge Rammern) and at the meso-scale (gauge Viehhofen).

Further areas must be involved in generating fast runoff, taking into account that the required size is calculated under the most unfavorable assumption of a runoff coefficient equal 1. These results are consistent with the results of Tilch et al. (2003). They could verify that the first peak does not only consist of event water from the saturation area and slide area, but also of pre-event water from the boulder field at the very steep slope.

\subsection{Runoff response at different scales}

Figures 8 and 9 show example recession limbs for all events of 1997, with linear curve fit and $q_{t}$ plotted on a logarithmic scale (Fig. 8) and with a nonlinear curve fit (Fig. 9) according to the model given by Wittenberg (1999) (see Sect. 3.4). The recession limbs are neither all concave shaped nor linear. For example, the bimodal events are more linear on a log scale but unimodal events are still concave shaped (Fig. 8). In opposite, recession limbs measured at Rammern are almost linear at normal scale (Fig. 9). Hence, two methods are applied, a semi-logarithmic method assuming a linear storagedischarge relationship and the method according to Wittenberg (1999) implying a nonlinear storage-discharge relationship.

The recession coefficients $K_{r}^{t}$, calculated from the linear model (Fig. 10), and $a$, calculated from the nonlinear model (Fig. 11), are significantly different for unimodal and bimodal event types for the small-catchment scale (gauge Rammern), as well as for the meso-scale (gauge Viehhofen). In both models the median $\mathrm{r}^{2}$ for the goodness of curve fit are around 0.9 , meaning that the fitted curves represent the runoff values $q$ and $\log q$ very well. These results show that the event types distinguished at the headwater Limberg with a size of $0.07 \mathrm{~km}^{2}$ can also be identified in the hydrographs at Rammern with a size of $15.5 \mathrm{~km}^{2}$, and at Viehhofen with a size of $150 \mathrm{~km}^{2}$. The differences can be shown by the coefficients $K_{r}^{t}$ and $a$ of the linear and the nonlinear outflow model, respectively. Both models are appropriate to illustrate 

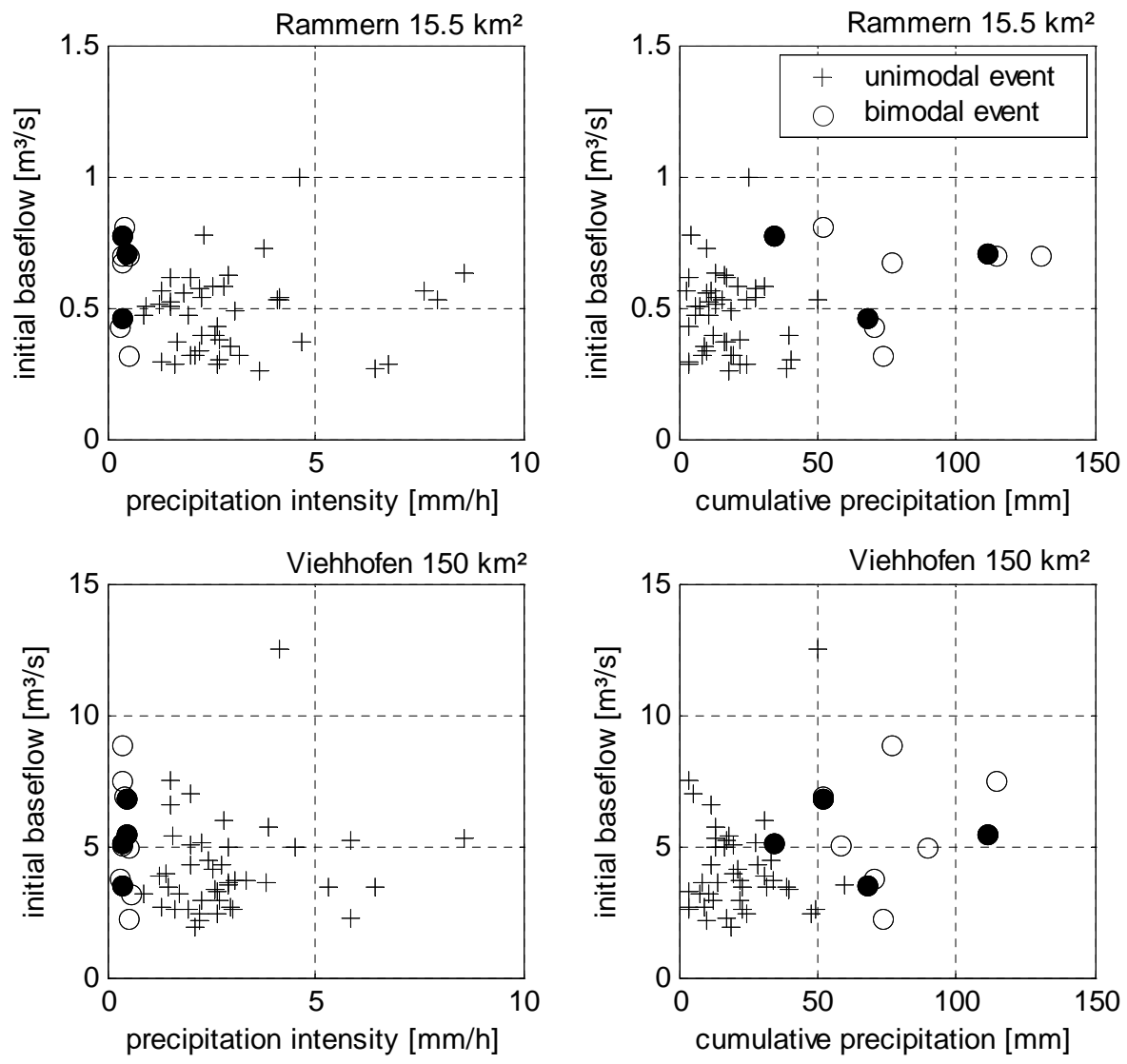

Fig. 12. Initial base flow versus cumulative precipitation, and initial baseflow versus precipitation intensity, for gauges Rammern and Viehhofen. Filled circles indicate bimodal events with underestimated precipitation due to measurement errors.
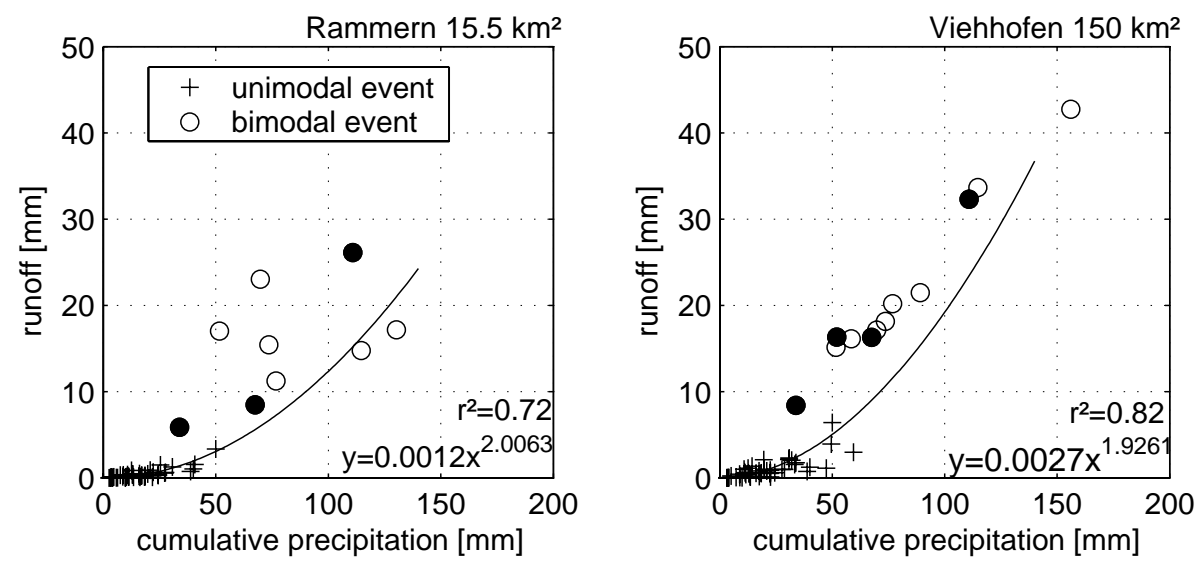

Fig. 13. Runoff versus cumulative precipitation for direct peak events and for bimodal events at two different scales. Total runoff from bimodal events is the runoff from both peaks, filled circles indicate bimodal events with underestimated precipitation due to errors in time series.

the different recession behavior of the unimodal and bimodal events.

The appearance of an event type at Limberg can be described by initial baseflow and cumulative precipitation (Fig. 6). Initial baseflow versus precipitation intensity, and initial baseflow versus cumulative precipitation are plotted in Fig. 12 for all events for Rammern and Viehhofen scales. At both scales, the same pattern as at the micro-scale (gauge Limberg) can be observed. Again, the two event types form two separate groups. There is one exception (Fig. 12, right), 
Table 5. Characteristics of the unimodal events measured at gauges Rammern and Viehhofen.

\begin{tabular}{lcccccccc}
\hline & \multicolumn{4}{c}{ Rammern } & \multicolumn{4}{c}{ Viehhofen } \\
& $\begin{array}{c}t_{e} \\
{[d]}\end{array}$ & $\begin{array}{c}q_{0} \\
{\left[\mathrm{~m}^{3} / \mathrm{s}\right]}\end{array}$ & $\begin{array}{c}q s \\
{\left[\mathrm{~m}^{3} / \mathrm{km}^{2}\right]}\end{array}$ & $\begin{array}{c}q s / p \\
{[-]}\end{array}$ & $\begin{array}{c}t_{e} \\
{[d]}\end{array}$ & $\begin{array}{c}q_{0} \\
{\left[\mathrm{~m}^{3} / \mathrm{s}\right]}\end{array}$ & $\begin{array}{c}q s \\
{\left[\mathrm{~m}^{3} / \mathrm{km}^{2}\right]}\end{array}$ & $\begin{array}{c}q s / p \\
{[-]}\end{array}$ \\
\hline median & 0.53 & 0.49 & 291 & 0.020 & 0.79 & 3.64 & 635 & 0.040 \\
minimum value & 0.17 & 0.26 & 9 & 0.004 & 0.25 & 1.87 & 23 & 0.005 \\
maximum value & 1.56 & 1.00 & 3361 & 0.070 & 2.52 & 12.51 & 6438 & 0.130 \\
\hline
\end{tabular}

$t_{e}$, event duration; $q_{0}$, initial baseflow; $q s$, storm runoff; $q s / p$, runoff coefficient

Table 6. Characteristics of the bimodal events measured at gauges Rammern and Viehhofen.

\begin{tabular}{|c|c|c|c|c|c|c|c|c|c|}
\hline \multirow[b]{2}{*}{ event } & \multirow[b]{2}{*}{ start } & \multicolumn{4}{|c|}{ Rammern } & \multicolumn{4}{|c|}{ Viehhofen } \\
\hline & & $\begin{array}{l}t_{e} \\
{[d]}\end{array}$ & $\begin{array}{l}q_{0} \\
{\left[\mathrm{~m}^{3} / \mathrm{s}\right]}\end{array}$ & $\begin{array}{l}q s \\
{\left[\mathrm{~m}^{3} / \mathrm{km}^{2}\right]}\end{array}$ & $\begin{array}{l}q s / p \\
{[-]}\end{array}$ & $\begin{array}{l}t_{e} \\
{[d]}\end{array}$ & $\begin{array}{l}q_{0} \\
{\left[\mathrm{~m}^{3} / \mathrm{s}\right]}\end{array}$ & $\begin{array}{l}q s \\
{\left[\mathrm{~m}^{3} / \mathrm{km}^{2}\right]}\end{array}$ & $\begin{array}{l}q s / p \\
{[-]}\end{array}$ \\
\hline$* 1$ & 22 June 1997 & 7.51 & 0.77 & 5871 & 0.17 & 7.51 & 5.15 & 8413 & 0.25 \\
\hline 2 & 5 July 1997 & 8.84 & 0.70 & 17185 & 0.13 & 9.19 & 3.18 & 42749 & 0.27 \\
\hline 3 & 17 July 1997 & 10.34 & 0.70 & 14772 & 0.13 & 10.34 & 7.47 & 33663 & 0.29 \\
\hline 4 & 7 July 1998 & 13.21 & 0.70 & 26126 & 0.23 & 13.21 & 5.49 & 32318 & 0.29 \\
\hline 5 & 21 June 1999 & - & - & - & & 10.42 & 6.86 & 16340 & 0.31 \\
\hline 6 & 9 July 1999 & - & - & - & & 11.32 & 5.08 & 16132 & 0.28 \\
\hline 7 & 22 July 1999 & - & - & - & & 11.22 & 4.96 & 21462 & 0.24 \\
\hline 8 & 26 Aug 1999 & 15.28 & 0.46 & 8464 & 0.21 & 15.95 & 3.55 & 16317 & 0.24 \\
\hline 9 & 10 July 2000 & 10.41 & 0.42 & 23032 & 0.32 & 10.42 & 3.80 & 17143 & 0.25 \\
\hline 10 & 5 Aug 2000 & 8.75 & 0.81 & 17020 & 0.32 & 8.75 & 6.87 & 15154 & 0.29 \\
\hline 11 & 16 June 2001 & 7.77 & 0.67 & 11262 & 0.14 & 7.77 & 8.90 & 20198 & 0.26 \\
\hline 12 & 19 July 2001 & 10.83 & 0.31 & 15426 & 0.20 & 10.70 & 2.21 & 18162 & 0.25 \\
\hline
\end{tabular}

$t_{e}$, event duration; $q_{0}$, initial baseflow; $q s$, storm runoff; $q s / p$, runoff coefficient precipitation is underestimated due to measurement errors and temperatures $<0^{\circ} \mathrm{C}$

namely the unimodal event at gauge Viehhofen with more than $50 \mathrm{~mm}$ precipitation and an initial baseflow of more than $12.5 \mathrm{~m}^{3} / \mathrm{s}$. This event occurred at Viehhofen during the extreme flood event in summer 2002. But this outlier can be distinguished from the bimodal event type due to a much higher precipitation intensity.

Runoff height is plotted versus precipitation height in Fig. 13. The relationships at both scales are nonlinear and are correlated with $r^{2}=0.72$ for Rammern and $r^{2}=0.82$ for Viehhofen. Higher runoff volumes are generated during bimodal events. The runoff coefficients of the bimodal events are between 0.13 and 0.32 for Rammern and 0.24 to 0.31 for Viehhofen (Table 6), whereas unimodal events just reach a runoff coefficient of 0.07 for Rammern and 0.13 for Viehhofen, respectively (Table 5). It follows that at this scales runoff coefficients of the bimodal events are much higher than those of the unimodal events, and the gap seems to increase with scale.

\section{Conclusions}

The results presented in this paper reveal a strong relationship between runoff response at the headwater scale $\left(0.07 \mathrm{~km}^{2}\right)$ and the response at larger scales (smallcatchment scale, $15.5 \mathrm{~km}^{2}$, and meso-scale, $150 \mathrm{~km}^{2}$ ) in the Saalach watershed. Based on the analysis of 67 rainfall runoff events (total: 201 at three scales), two different event types could be identified at these three scales: (1) an unimodal event type, characterized by a quick rising and falling hydrograph, responding to short duration rainfall, and (2) a bimodal event type, consisting of a first peak with a quick rise and fall, and a second peak, when the rain has already stopped, with a much slower rise and fall. The second peak has a delay of three to five days. It has been shown that if a delayed peak occurs at the gauge Limberg, substantially increased flow values arise at the larger gauges Rammern and Viehhofen. For these events, the damped recession of Rammern and Viehhofen is explained by the superposition of different delayed peaks, originating from different headwaters in the area. Due to diverse distances between source 
areas and stream gauge, and due to variable flow accumulation and flow concentration, the overlay of several damped hydrographs results in an increased runoff of prolonged duration. This link between the scales means that the runoff behavior of the headwater (Limberg, $0.07 \mathrm{~km}^{2}$ ) may be used as an indicator of the runoff behavior of much larger areas (Rammern, $15.5 \mathrm{~km}^{2}$, Viehhofen, $150 \mathrm{~km}^{2}$ ). It is interesting to note that the occurrence of the two event types is consistent over three orders of magnitude in area.

At all three scales, the occurrence of an event type depends on the rainfall amount and on the initial baseflow. A low rainfall height can produce a bimodal event only if the initial baseflow is high. For low initial baseflow, a high rainfall volume is necessary to generate a delayed peak. Therefore, the bimodal events seem to result from an overflow of deeper storage systems where, depending on the current water content, more or less rain input is needed to initiate a delayed peak response.

During bimodal events, considerably higher runoff volume is generated at all scales. Investigations at the headwater Limberg let come to the conclusion that the higher amount of runoff of bimodal events consists of pre-event water, generated by subsurface flow processes. This reveals that beside saturation areas subsurface compartments can be significantly involved in the flood generation process.

Acknowledgements. The authors would like to thank the German Science Foundation (DFG), project Me 1844/1-3, for financial support. We would also like to thank the Austrian Hydrographic Service - Salzburg Section - for providing hydrographic data for runoff gauge Viehhofen.

\section{Edited by: M. Mikos}

\section{References}

Aksoy, H. and Wittenberg, H.: Jahreszeitliche Veränderung der Trockenwetterganglinie - Fallstudie für einen Fluss im europäischen Teil der Türkei, Wasserwirtschaft, 90, 38-41, 2001.

Anderson, M. G. and Burt, T. P.: The role of topography in controlling throughflow generation, Earth Surf. Processes, 3, 331-344, 1978.

Chapman, T.: A comparison of algorithms for stream flow recession and baseflow separation, Hydrol. Processes, 13, 701-714, 1999.

Dewandel, B., Lachassagne, P., Bakalowicz, M., Weng, P., and AlMalki, A.: Evaluation of aquifer thickness by analyzing recession hydrographs. Application to the Oman Ophiolite hard-rock aquifer, J. Hydrol., 274, 248-269, 2003.

Gutknecht, D.: Abflussentstehung an Hängen - Beobachtungen und Konzeptionen, Österreichische Wasser- und Abfallwirtschaft, 48, 134-144, 1996.

Grayson, R. and Blöschl, G.: Spatial processes, organisation and patterns, in: Spatial patterns in catchment hydrology. Observations and modelling, edited by: Grayson, R. and Blöschl, G., Cambridge University Press, 3-16, 2000.

Hall, F. R.: Baseflow recessions - a review, Water Resour. Res., 4973-4983, 1968.
HDÖ (Ed.): Hydrographisches Jahrbuch von Österreich 1999 , Bundesministerium für Land- und Forstwirtschaft, Umwelt und Wasserwirtschaft, Wien, 2002.

Jenkins, A., Ferrier, R. C., Harriman, R., and Ogunkoya, Y. O.: A case study in catchment hydrochemistry: Conflicting interpretations from hydrological and chemical observations, Hydrol. Processes, 8, 335-349, 1994.

Kirnbauer, R., Blöschl, G., Haas, P., Müller, G., and Merz, B.: Identifying space-time patterns of runoff generation in the Löhnersbach catchment, in: Runoff generation and implications for river basin modelling, Freiburger Schriften zur Hydrologie, 13, 37-45, 2001.

Kirnbauer, R., Tilch, N., Markart, G., Zillgens, B., Kohlbeck, F., Leroch, K., Seidler, C., Haas, P., Uhlenbrook, S., Didszun, J., Leibundgut, C., Merz, B., Chawatal, W., and Fürst, J.: Runoff generation in the northern greywack zone of the Alps - field studies and mathematical modeling, in: 10. Kongress Interpraevent in Garda 2004, 24-27 May 2004, vol. II, 45-56, 2004.

Kirnbauer, R., Pirkl, H., Haas, P., and Steidl, R.: Runoff processes - observations and modelling, Österreichische Wasser- und Abfallwirtschaft, 48, 15-26, 1996.

Kirnbauer, R., Blöschl, G., Haas, P., Müller, G., and Merz, B.: Identifying space-time patterns of runoff generation - A case study from the Löhnersbach catchment, Austrian Alps, in: Global change and mountain regions - a state of knowledge overview, edited by: Huber, U., Bugmann, H., and Reasoner, M., Springer Verlag, 309-320, 2005.

Klemes, V.: Probability of extreme hydrometeorological events - a different approach, in: Extreme Hydrological Events: Precipitation, Floods and Droughts, 213, 167-176, 1993.

Kubota, J. and Sivapalan, M.: Towards a catchment-scale model of subsurface runoff generation based on synthesis of small-scale process-based modelling and field studies, Hydrol. Processes, 9, 541-554, 1995.

Markart, G. and Kohl, B.: Die Böden im Einzugsgebiet des Löhnerbaches/Saalbach. Unveröffentlichter Projektbericht an das BMLF (unpublished report), Wien, 1993a.

Markart, G. and Kohl, B.: Beregnungen im Einzugsgebiet des Löhnerbaches/Saalbach, Unveröffentlichter Projektbericht an das BMLF (unpublished report), Wien, 1993b.

Masiyandima, M. C., van de Giesen, N., Diatta, S., Windmeijer, P. N., and Steenhuis, T. S.: The hydrology of inland valleys in the sub-humid zone of West Africa: rainfall-runoff processes in the M'bé experimental watershed, Hydrol. Processes, 17, 12131225, 2003.

McDonnell, J. and Woods, R.: On the need for catchment classification (editorial), J. Hydrol., 299, 2-3, 2004.

McNamara, J. P., Kane, D. L., and Hinzman, L. D.: An analysis of streamflow hydrology in the Kuparuk River basin, Arctic Alaska; a nested watershed approach, J. Hydrol., 206, 39-57, 1998.

Mendoza, G. F., Steenhuis, T. S., Walter, M. T., and Parlange J.Y.: Estimating basin-wide hydraulic parameters of a semi-arid mountainous watershed by recession-flow analysis, J. Hydrol., 279, 57-69, 2003.

Mishra, A., Hata, T., Abdelhadi, A. W., Tada, A., and Tanakamaru, H.: Recession flow analysis of the Blue Nile River, Hydrol. Processes, 17, 2825-2835, 2003.

Morgali, J. R. and Linsley, R. K.: Computer Analysis of Overland Flow, J. Hydraul. Div., Proc. ASCE, 91, HY 5, 81-100, 1965. 
Naef, F., Scherrer, S., and Weiler, M.: A process based assessment of the potential to reduce flood runoff by land use change, J. Hydrol., 267, 74-79, 2002.

Nathan, R. J. and McMahon, T. A.: Evaluation of automated techniques for base flow and recession analyses, Water Resour. Res., 26, 1465-1473, 1990.

Onda, Y., Komatsu, Y., Tsujimura, M., and Fujihara, J. I.: The role of subsurface runoff through bedrock on storm flow generation, Hydrol. Processes, 15, 1693-1706, 2001.

Pilgrim, D. H. and Cordery, I.: Flood Runoff, in: Handbook of Hydrology, edited by: Maidment, D. R., McGraw-Hill Inc., 9.19.42, 1993.

Pirkl, H.: Erarbeitung der Zusammenhänge zwischen Hanginstabilitäten und -labilitäten, Hangwasserhaushalt und Massenbewegungen in Teilen des Zentralalpenkristallins, Österreichische Akademie der Wissenschaften, Geologische Bundesanstalt (unpublished report), Wien, 1989.

Rodda, J. C.: Mountains - a hydrological paradox or paradise?, Beiträge zur Hydrologie der Schweiz, 41-51, 1994.

Rose, S. and Peters, N. E.: Effects of urbanization on streamflow in the Atlanta area (Georgia, USA): A comparative hydrological approach, Hydrol. Processes, 15, 1441-1457, 2001.

Schiffer, R. and Burgstaller, B.: Vegetationskartierung Löhnersbach, Thematische Karte (unpublished report), 1990.

Singh, V. P. and Strupczewski, W. G.: On the status of flood frequency analysis, Hydrol. Processes, 16, 3737-3740, 2002.

Sujono, J., Shikasho, S., and Hiramatsu, K.: A comparison of techniques for hydrograph recession analysis, Hydrol. Processes, 18, 403-413, 2004.

Tallaksen, L. M.: A review of baseflow recession analysis, J. Hydrol., 165, 349-370, 1995.

Tilch, N., Uhlenbrook, S., Didszun, J., Leibundgut, C., Zillgens, B., Kirnbauer, R., and Merz, B.: Decoding flow formation processes using tracer hydrologic methods in an Alpine catchment, Österreichische Wasser- und Abfallwirtschaft, 55, 9-17, 2003.
Uhlenbrook, S., Frey, M., Leibundgut, C., and Maloszewski, P.: Hydrograph separations in a mesoscale mountainous basin at event and seasonal timescales, Water Resour. Res., 38(6), 1096, doi:10.1029/2001WR000938, 2002.

Vitvar, T., Gurtz, J., and Lang, H.: Application of GIS-based distributed hydrological modelling for estimation of water residence times in the small Swiss pre-alpine catchment Rietholzbach, IAHS-AISH-Publication, 258, 241-248, 1999.

Viviroli, D., Weingartner, R., and Messerli, B.: Assessing the hydrological significance of the world's mountains, Mt. Res. Dev., 23, 32-40, 2003.

Weiler, M., McGlynn, B. L., McGurie, K. J., and McDonnell, J. J.: How does rainfall become runoff? A combined tracer and runoff transfer function approach, Water Resour. Res., 39(11), 1315, doi:10.1029/2003WR002331, 2003.

Weingartner, R., Barben, M., and Spreafico, M.: Floods in mountain areas - an overview based on examples from Switzerland, J. Hydrol., 282, 10-24, 2003.

Wetzel, K. F.: Runoff production processes during different rainfall in small hillslope catchments of the northern limestone Alps, Erde, 132, 361-379, 2001

Wittenberg, H.: Nonlinear analysis of flow recession curves, IAHSPublication, 221, 61-67, 1994.

Wittenberg, H.: Baseflow recession and recharge as nonlinear storage processes, Hydrol. Processes, 13, 715-726, 1999.

Wittenberg, H.: Effects of season and man-made changes on baseflow and flow recession - case studies, Hydrol. Processes, 17, 2113-2123, 2003.

Wittenberg, H. and Sivapalan, M.: Watershed groundwater balance estimation using streamflow recession analysis and baseflow separation, J. Hydrol., 219, 20-33, 1999. 